\title{
PERSEPSI ULAMA KOTA BANJARMASIN TERHADAP TINDAKAN ANAK YANG MENEMPATKAN ORANG TUANYA DI PANTI JOMPO DALAM PERSPEKTIF ETIKA ISLAM
}

\author{
Rahmawati dan Ahmad Syadzali \\ Jurusan Akidah Filsafat Fakultas Ushuluddin dan Humaniora \\ IAIN Antasari Banjarmasin \\ Diterima tanggal 11 Pebruari 2015 / Disetujui tanggal 9 Maret 2015
}

\begin{abstract}
This study wants to tell about a fact that there many people have less awareness with their duty as a child to their parents aged, moreover when they have a good position and have many activities with his jobs. Some children put their parents in an old folks' home because they cannot take after them well. This action absolutely does not reflect an implementation of command of Allah that is to dedicate to their parents. Because of that, it needs to have responses of Ulama about this problem and it needs to get explanations about children's ethics on their parents as well as teaching in Islam.
\end{abstract}

Kata kunci: Persepsi, ulama, panti jompo, dan etika Islam.

\section{Pendahuluan}

Orang tua ialah manusia yang paling dekat hubungannya dengan anaknya, karena mereka adalah asal jasmani dari anaknya. ${ }^{1}$ Tiada orang yang jasanya melebihi dari jasa orang tua kepada anaknya. Keduanya telah menanggung kesulitan dalam memelihara dan merawat anak-anaknya. ${ }^{2}$ Allah swt. meletakkan perintah berterima kasih kepada ibu bapak langsung sesudah perintah berterima kasih kepada Allah swt (QS. Luqman 14).

Pada fase bayi, manusia membutuhkan uluran tangan orang lain, terutama ibu bapaknya untuk membantu mereka memenuhi kebutuhannya. ${ }^{3}$ Sebaliknya, setelah orang tua lanjut usia, maka merekalah yang membutuhkan ulur tangan dari anak-anaknya yang telah tumbuh dewasa untuk membantu segala kebutuhan mereka. Selain tercukupinya kebutuhan sandang, pangan, dan tempat berteduh, hal yang paling dibutuhkan orang tua pada masa senjanya adalah pelayanan dan pergaulan yang baik dari anak-anaknya. ${ }^{4}$

Orang tua yang sudah lanjut usia kadang-kadang lemah (tidak mampu melaksanakan kepentingan dirinya), sehingga mereka sangatlah membutuhkan bantuan dari orang lain terutama anaknya, oleh karenanya kesejahteraan hidup orang tua lanjut usia harus diperhatikan dengan baik. ${ }^{5} \mathrm{Hal}$ inilah yang seharusnya kita sadari agar kepentingan orang-orang lanjut usia terlindungi sepenuhnya sejalan dengan tuntutan Islam. ${ }^{6}$

\footnotetext{
${ }^{1}$ Kahar Masyhur, Membina Moral dan Akhlak, (Jakarta: Rineka Cipta, 1994), h. 162.

${ }^{2}$ Burhanuddin Salam, Etika Sosial Asas Moral Dalam Kehidupan Manusia, (Jakarta: Rineka Cipta, 1997), h. 19.

${ }^{3}$ M. Thalib, 20 Perilaku Durbaka Anak Terhadap Orang Tua, (Bandung: Irsyad Baitus Salam/IBS, 1996), h. 101.

${ }^{4}$ M. Thalib, 40 Tanggung Jawab Anak Terhadap Orang Tua, (Bandung: Irsyad Baitus Salam/IBS, 1995), h. 77.

${ }^{5}$ Abdullah Ahmad Qodiry Al-Ahdal, Tanggung Jawab dalam Islam, (Semarang: Dina Utama, 1992), h. 68.

${ }^{6}$ M. Thalib, 20 Perilaku Durbaka Anak..., h. 101.
} 
Islam dengan jelas memerintahkan agar anak harus berbuat baik kepada kedua orang tuanya dan hukumnya wajib. ${ }^{7}$ Terbukti dengan banyaknya ayat dalam al-Qur'an tentang perintah tersebut (QS. 17: 23, 2: 83, 6: 151, 29: 8, 46: 15, dan 31: 14-15). Oleh karenanya, anak dituntut untuk berbuat kebaikan sebaik-baiknya kepada kedua orang tuanya dan dilarang keras mendurhakai keduanya. ${ }^{8}$

Namun, pada kenyataannya menitipkan orang tua di panti jompo sekarang sudah menjadi pilihan bagi kebanyakan anak yang tidak bisa merawat sendiri orang tuanya. Jelas tidak mencerminkan kehendak dari perintah untuk berbakti tersebut anak yang menempatkan orang tuanya di panti jompo. Hal inilah yang benar-benar harus menjadi perhatian orang-orang modern sekarang. ${ }^{9}$ Pokok permasalahan yang ingin dijawab adalah bagaimana pandangan ulama terhadap tindakan anak yang menempatkan orang tuanya yang sudah berusia lanjut di panti jompo? Bagaimana peran ulama dalam meningkatkan rasa tanggung jawab anak terhadap orang tuanya? Bagaimana perspektif etika Islam terhadap pandangan ulama atas tindakan anak yang menempatkan orang tuanya di panti jompo? 9 orang ulama yang dimintai keterangan dalam tulisan ini, penulis anggap mempunyai wawasan luas, sehingga dapat memberikan informasi secara mendalam.

Uraian selanjutnya mencoba memberikan penjelasan tentang permasalahan tersebut, dengan demikian diharapkan nantinya diperoleh kejelasan bagaimana Islam yang dikenal sebagai agama rahmatan lil'alamin itu mampu memberikan antisipasi atau alternatif pemecahan masalah yang memberi kemungkinan kepada kita untuk mengambil sikap sendiri serta ikut menentukan arah perkembangan masyarakat.

\section{Etika Anak Terhadap Orang Tua dalam Ajaran Islam}

Sumber etika Islam adalah al-Qur'an dan hadis, yang menjelaskan bagaimana berbuat baik, yang mana keduanya merupakan pedoman hidup yang menjadi asas bagi setiap muslim. Etika Islam memperhatikan secara komprehensif, mencakup hubungan manusia dengan sesama manusia (hablumminannas) dan juga kepada makhluk-Nya yang lain: seperti hewan dan tumbuhan, juga kepada Tuhannya (bablumminallah). ${ }^{10}$ Akhlak keluarga adalah pemenuhan kewajiban seseorang terhadap keluarganya, baik jasmaniah maupun rohaniah. Kepada kedua orang tua supaya berbuat ihsan; jika orang tua lanjut usia dan ada di bawah pemeliharaannya jangan sampai anak menunjukkan sikap kurang hormat; jangan disakitkan hati mereka dengan katakata yang membentak tetapi berkatalah yang baik-baik kepada mereka. Kepada orang tua anak supaya merendahkan diri atas dasar kasih sayang, serta selalu memohon ampunan dan kasih sayang Allah, seperti halnya orang tua yang telah mencurahkan kasih sayang dan mendidik anaknya sewaktu masih kecil (QS. 17: 23-24). ${ }^{11}$

\footnotetext{
${ }^{7}$ Abu Ghuddah, Abdul Fattah, 35 Adab Islam, (Jakarta: Pustaka Al-Kautsar, 1996), h. 71.

${ }^{8}$ Ilyas, Yunahar, Kuliah Akblaq, (Yogyakarta: Lembaga Pengkajian dan Pengalaman Islam (LPPI), 1999), h. 152.

${ }^{9}$ M. Thalib, 40 Tanggung Jawab Anak...., h. 78.

${ }^{10}$ Istighfarotur Rahmaniyah, Pendidikan Etika, Konsep Jiwa dan Etika Perspektif Ibnu Miskawaih dalam Kontribusinya di Bidang Pendidikan, (Malang: UIN-Maliki Press, 2010), h. 94-96.

${ }^{11}$ Ahmad Azhar Basyir, Refleksi Atas Persoalan Keislaman, Seputar Filsafat Hukum, Politik dan Ekonomi, (Bandung: Mizan, 1994), h. 228.
} 


\section{Adab Berbakti Kepada Orang Tua menurut Filsuf Islam}

\section{Pemikiran Ibnu Miskawaih tentang etika anak terhadap orang tua}

Ibnu Miskawaih (320-421 H/932-1030 M), seorang filsuf Islam yang telah menyumbangkan pikirannya di bidang akhlak atau etika. Nama lengkapnya Ibnu Ali al-Khozin Ahmad Ibnu Muhammad bin Ya'kub lebih dikenal dengan Ibnu Miskawaih. Miskawaih adalah salah seorang filsuf Muslim yang menitikberatkan perhatiannya pada Etika Islam. Meskipun sebenarnya iapun seorang sejarawan, tabib, ilmuwan dan sastrawan. Cabang filsafat yang paling didalaminya adalah bidang etika/akhlak. ${ }^{12}$

Menurutnya, seseorang tidak bisa dikatakan adil, kalau dia belum melaksanakan apa yang terbaik bagi keluarganya, terutama kepada kedua orang tuanya. ${ }^{13}$ Dibanding cinta orang tua terhadap anaknya, cinta anak terhadap orang tuanya lebih rendah derajatnya, karena anak dilahirkan dan tidak tahu dirinya dan juga tidak tahu siapa yang melahirkannya, kecuali setelah berlalunya waktu yang lama dan setelah dia bergaul erat dengan orang tuanya serta banyak mengambil manfaat dari orang tuanya untuk waktu yang lama. Dari situlah anak memahami kondisinya dengan benar. Perlakuan hormatnya pada orang tua dan kecintaan pada mereka bergantung pada pikiran dan wawasannya tentang keadaan segala sesuatu. Itulah mengapa Allah Azqa wa Jalla memerintahkan agar anak memperhatikan kedua orang tuanya, dan tak memerintahkan agar orang tua menghormati anaknya. ${ }^{14}$ Pemikiran Al-Ghazali tentang etika anak terhadap orang tua

Nama lengkapnya adalah Muhammad Ibn Muhammad al-Thusi al-Imam al-Jalil Abu Hamid al-Ghazali. Gelarnya antara lain Hujjat al-Islam, Zayn al-Din, al-Faylasuf al-mutakallim almutashawwif al-faqih, dengan kitabnya Ihya 'Ulumuddin. Ia dilahirkan di Thus salah satu kota yang ada di Khurasan pada tahun $450 \mathrm{H} / 1058 \mathrm{M}$, di kota Naisabur ia meninggal pada usia 55 tahun. ${ }^{15}$ Al-Ghazali sangat aktif dan produktif dalam melahirkan tulisan terbukti dengan banyaknya buku-buku karyanya.

Mengenai adab seorang anak terhadap orang tua, Imam al-Ghazali menjelaskannya sebagai berikut:

1. Hendaklah ia mendengarkan dan mengikuti segala perkataan orang tuanya.

2. Hendaklah ia berdiri ketika orang tuanya berdiri karena menghormatinya.

3. Hendaklah ia menjunjung segala perintah keduanya, selama yang diperintahkan oleh keduanya tidak menyalahi syariat Islam.

4. Jangan ia berjalan mendahului di saat berjalan di hadapan keduanya.

5. Jangan ia mengangkat suara lebih tinggi dari keduanya, saat berbicara dengan keduanya.

6. Hendaklah ia memperkenankan panggilan keduanya dengan menyegerakan diri menghampirinya.

\footnotetext{
${ }^{12}$ Sirajuddin Zar, Filsafat Islam: Filosof \& Filsafatnya, (Jakarta: Rajawali Pers, 2010), h. 115-117.

${ }^{13}$ Ibn Miskawaih, Menuju Kesempurnaan Akblak: Buku Daras Pertama Tentang Filsafat Etika, Terj. Helmi Hidayat, cet ke-5, (Bandung: Mizan, 1999), h. 49.

${ }^{14}$ Ibn Miskawaih, Menuju Kesempurnaan Akblak..., h. 142.

${ }^{15}$ Rahmadi, Guru dan Murid dalam Perspektif Al-Mawardi dan Al-Ghazali, Cet. I, (Banjarmasin: Antasari Press, 2008), h. 
7. Hendaklah ia senantiasa menuntut keridhaan keduanya.

8. Hendaklah ia bersikap tawadhu' kepada keduanya.

9. Jangan ia menyebut-nyebut jasanya kepada keduanya dan jangan pula ia menyebut apa-apa perkhidmatannya bagi keduanya.

10. Janganlah ia melihat kepada keduanya dengan pandangan penghinaan.

11. Janganlah ia memasamkan mukanya di hadapan keduanya.

12. Janganlah ia musafir kecuali setelah mendapat izin dari keduanya. ${ }^{16}$

Menurutnya, dalam berbakti seorang anak hendaklah senantiasa mendengarkan segenap ucapan orang tua: melaksanakan perintah mereka dan memenuhi panggilan mereka. Menghormati mereka dengan merendahkan diri di hadapan keduanya dengan penuh kasih sayang. Tidak membuat mereka jemu dengan permintaan yang terus-menerus. Tidak berbuat baik kepada mereka dan melaksanakan perintah mereka, semata-mata atas dasar balas jasa karena kebaikan mereka. Tidak memandangi dengan sikap marah dan tidak mendurhakai perintah mereka. ${ }^{17}$ Pemikiran Nashir al-Din ath-Thusi tentang etika anak terhadap orang tua

Khawaja Nasir al-Din Abu Ja'far Muhammad Ibn Muhammad ibn Hasan, yang lebih dikenal dengan Nashir al-Din ath-Thusi, adalah seorang ahli matematika, astronomi dan politisi Syi'ah pada masa penyerangan bangsa Mongol atas para pembunuh dan khalifah. Lahir di Thus pada tahun 597 H/1201 M. Karya-karyanya kebanyakan bersifat eklektis (bersifat memilih yang terbaik dari berbagai sumber, baik itu tentang orang, gaya dan metode). ${ }^{18}$ Salah satu karya penting filsafatnya adalah Akblaq-i Nasiri (kitab tentang etika). ${ }^{19}$

Ath-Thusi mendefinisikan rumah (manzil) sebagai hubungan istimewa antara suami dan isteri, orang tua dan anak, tuan dan hamba serta kekayaan dan pemiliknya. Tujuan ilmu rumah tangga (tadbir-i manzil) adalah mengembangkan sistem disiplin yang mendorong terciptanya kesejahteraan fisik, sosial dan mental orang-orang di dalamnya. ${ }^{20}$

Mengenai disiplin anak-anak, ath-Thusi yang mengikuti pendapat Ibnu Miskawaih, memulai dengan penanaman moral yang baik lewat pujian, hadiah dan celaan yang halus. Dia tidak menyukai celaan yang sering diucapkan serta teguran terbuka; celaan yang sering diucapkan akan meningkatkan godaan, sedang teguran terbuka akan mengundang keberanian. Setelah memberi mereka aturan-aturan makan, berpakaian, bercakap-cakap, bersikap dan tata-cara bergaul dalam masyarakat, anak-anak harus dilatih untuk memilih pekerjaan yang sesuai dengan mereka. Anak perempuan harus dilatih untuk menjadi isteri serta ibu yang baik dalam rumah tangganya nanti. ${ }^{21}$

Secara psikologis, anak-anak baru bisa menyadari hak-hak ayahnya setelah mereka mencapai usia yang membuat mereka bisa membeda-bedakan sesuatu, sedang mengenai hakhak ibunya, mereka telah melihat dengan jelas sejak awal sekali. Dari sini ath-Thusi berkesimpulan bahwa hak-hak ayah terutama bersifat mental, sedangkan hak-hak ibu bersifat fisik. Jadi dari

${ }^{16}$ Imam al-Ghazali, Bidayatul-Hidayah (Permulaan Jalan Hidayah), terj: Ahmad Fahmi bin Zamzam (Abu Ali AlBanjari An-Nadwi Al-Maliki), Cet. I, (Banjarbaru: Toko Buku “Darussalam Yasin”, 2013), h. 151.

${ }^{17}$ Imam Ghazali, Risalah-risalah Al-Ghazali, terj. Irwan Kurniawan, Cet. I, (Bandung: Pustaka Hidayah, 1997), h. 39.

${ }^{18}$ M.M. Syarif, History of Muslim Philosophy, terj. (Bandung: Mizan, 1996), h. 238.

${ }^{19}$ M.M. Syarif, History of Muslim Philosophy, h. 239.

${ }^{20}$ M.M. Syarif, History of Muslim Philosophy, h. 239.

${ }^{21}$ M.M. Syarif, History of Muslim Philosophy, h.245. 
ayahnya seseorang merasa berhutang karena pengabdian tanpa pamrih sang ayah, dan dari ibunya karena disediakannya makanan, pakaian dan kenyamanan-kenyamanan fisik lainnya.

Ringkasnya, bagi ath-Thusi, rumah adalah pusat kehidupan keluarga. Pemasukan, tabungan, pengeluaran dan disiplin isteri, anak serta pelayanan, semuanya merupakan pencipta kesejahteraan keluarga. ${ }^{22}$

\section{Tanggung Jawab Anak Terhadap Orang Tua}

Kendala yang sering merintangi para anak untuk mengurus orang tuanya yang telah lanjut usia adalah kemauan dan ketulusan. Sangat jarang anak-anak memiliki keikhlasan mengurus orang tuanya yang telah lanjut usia karena berbagai kepentingan yang sifatnya sangat egoistis. Sebab utamanya adalah kemauan yang kuat untuk mengurus orang tua itu tidak dimiliki oleh anak, padahal waktu masa kecil kepentingannya diurusi oleh orang tua.

Pada masa kecil, seorang anak juga telah sering membuat kerepotan pada ibu dan bapaknya. Oleh sebab itu, anak yang tidak mau mengurus orang tuanya yang sudah lanjut usia, padahal menjadi tanggung jawabnya untuk memenuhi kepentingan orang tuanya, apalagi pada saat orang tuanya jompo, berarti telah berbuat durhaka. ${ }^{23}$

Orang tua lanjut usia secara fisik lemah dan sering sakit-sakitan, kondisi psikologis kebanyakan mereka kehilangan daya ingatnya, maka mereka tidak mampu berkonsentrasi terhadap suatu masalah sehingga terlihat selalu kebingungan. Jadi, kesabaran dan ketekunan serta kesiapan mental anak merawat dan mengasuh orang tua lanjut usia sangatlah diperlukan agar berhasil mengurus kepentingannya dengan baik, karena perlakuan anak kepada orang tuanya yang lanjut usia adalah seperti orang dewasa memperlakukan anak-anak kecil bahkan lebih berat daripada itu. ${ }^{24}$

\section{Hak Orang Tua dan Kewajiban Anak Terhadapnya Ketika Ia Sudah Lanjut Usia}

Salah satu yang paling utama dalam menentukan kelak anak itu menjadi orang yang baik atau tidak adalah orang tuanya. Para orang tua sebagai pihak yang paling bertanggung jawab menjadikan anak-anaknya berjiwa mandiri, harus selalu memberikan contoh dan latihan kepada anak-anaknya untuk hidup, mengurus keperluannya, dan menghadapi atau memecahkan persoalan secara mandiri tanpa melibatkan orang tua sesuai dengan tingkat umur dan kemampuan mereka. Para orang tua harus menyadari bahwa manusia harus berjiwa mandiri dan bekerja mandiri, tidak hanya dalam kehidupan di dunia, tetapi di akhirat kelak akan menghadapi pengadilan Allah secara sendiri-sendiri juga. Oleh karena itu, perlu sekali orang tua atau guru memahami dan menerapkan sikap mandiri pada anak sehingga mereka kelak dapat menjalani kehidupannya dengan penuh tanggung jawab dan menjalankan kehidupan sebagai hamba Allah dengan sebaik-baiknya. ${ }^{25}$

Banyak orang tua beranggapan bahwa memperlakukan anak tertentu lebih dari yang lain karena ia lebih pandai daripada yang lain sebagai hal yang lumrah. Anggapan seperti ini sama

\footnotetext{
${ }^{22}$ M.M. Syarif, History of Muslim Philosophy, h. 245-246.

${ }^{23}$ M. Thalib, 20 Perilaku Durbaka Anak..., h. 102-103.

${ }^{24}$ M. Thalib, 20 Perilaku Durbaka Anak..., h. 105.

${ }^{25}$ M. Thalib, Seni \& Sikap Islami Mendidik. Anak, Cet. I, (Bandung: Irsyad Baitus Salam, 2001), h. 71-74.
} 
sekali tidak benar. Orang tua hendaknya tetap berpegang pada prinsip bahwa anak mereka berhak mendapat perlakuan adil tanpa boleh dibedakan pandai atau bodoh, cantik atau jelek, dan sebagainya.

Orang tua harus berlaku adil dalam semua hal yang menyangkut perlakuan yang bersifat lahiriah, seperti kebutuhan makan, biaya belajar, kebutuhan buku, pakaian, dan hal-hal materiil lainnya. Adapun mengenai rasa sayang atau cinta orang tua kepada anak-anaknya tidaklah dapat diatur karena menyangkut perasaan yang tidak dikuasai oleh manusia dan hanya Allah yang berkuasa menetapkannya dalam hati seseorang. Untuk urusan ini orang tua tidak dituntut berlaku adil sebagaimana dalam urusan materiil.

Para orang tua wajib memperhatikan perlakuan adil kepada anak-anaknya supaya anakanak memahami bahwa berlaku adil adalah satu kewajiban agama yang diperintahkan oleh Allah dan Rasul-Nya sebagai perwujudan ketaatannya kepada Allah dan Rasul-Nya. Oleh karena itu, para orang tua perlu benar-benar memperhatikan seni mendidik anak dengan adil ini sehingga anak-anaknya kelak benar-benar merasakan bahwa Islam merupakan jalan hidup yang memberikan jaminan kepada manusia untuk mendapatkan keadilan yang dikehendaki dan dituntut oleh fitrah manusia. ${ }^{26}$ Agar kelak ia dapat berlaku adil terhadap kedua orang tuanya, sebagai bentuk balas jasa (kebaktian) atas perawatan dan pemeliharaan orang tua kepadanya sewaktu masih kecil.

Kedua orang tua itu sangat mulia dan sangat menentukan hidup anak-anaknya, jika mereka mampu meridhakannya, maka Allah pun ridha, apabila anak-anak membuat marah kedua orang tuanya, maka Allah pun akan marah dan murka padanya. ${ }^{27}$

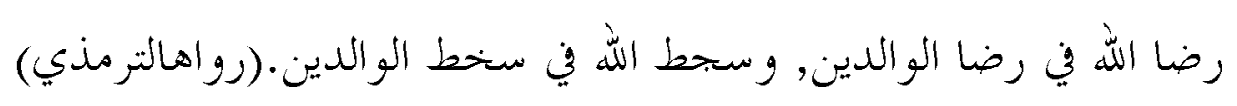

Terutama seorang ibu yang begitu besar jasanya ketika mengandung, melahirkan, menyusui, menjaga, dan memelihara anaknya. Hanya, ibu dengan keibuannya dan tak seorang manusia pun yang tidak memerlukannya. ${ }^{28}$ Itulah sang ibu, maka karena amat mulianya, Allah menetapkan bahwa surga itu di bawah telapak kaki ibu dan ia mempunyai hak untuk dihargai anak-anaknya tiga kali lipat dari ayah. ${ }^{29}$

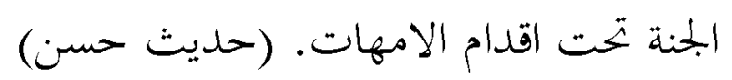

Siapa yang berbakti pada kedua orang tuanya dan suka berbuat baik padanya, maka sesungguhnya mereka bersyukur atas Tuhannya, dan siapa yang berdurhaka pada mereka, maka berarti ia kufur nikmat (tidak syukur nikmat). Orang tua adalah pintu masuk surga, maka siapa yang berbuat baik dan berkhidmat pada mereka, akan masuk ke surga, sedang siapa yang berbuat durhaka pada mereka, maka tidak akan dapat masuk surga. ${ }^{30}$

\footnotetext{
${ }^{26}$ M. Thalib, Seni \& Sikap Islami Mendidik. Anak, h. 117-118.

${ }^{27}$ Imam adz-Dzahabi, Dosa-dosa Besar: Kunci Masuk Surga Bagi yang Mengbindarinya, terj. Muammal Hamidy, Cet. II, (Surabaya: PT. Bina Ilmu, 2005), h. 64.

${ }^{28}$ Hasan Ayyub, Etika Islam (Menuju Kebidupan Yang Hakiki), terj. Tarmana Ahmad Qasima dkk., (Bandung: Trigenda Karya, 1994), h. 323).

${ }^{29}$ Imam adz-Dzahabi, Dosa-dosa Besar..., h. 64.

${ }^{30}$ Hasan Ayyub, Etika Islam..., h. 320-321.
} 
Islam memperingatkan anak-anak, bahwa menyakiti perasaan orang tua merupakan suatu dosa besar dan wajib atasnya untuk selalu menjaga perasaan orang tuanya. Hak kedua orang tua tidak sama dengan hak siapa pun di dunia ini. Jadi segala bentuk ucapan atau isyarat yang akan menyakiti perasaan keduanya atau salah satunya, merupakan perbuatan dosa. ${ }^{31}$

Para orang tua merasakan adanya darma bakti dan perilaku yang baik dari anak-anaknya melalui lidah dan sikap-sikapnya. Misalnya ketika masuk ke rumah mengucapkan salam, bila hendak keluar rumah meminta izin, membantu pekerjaannya atau memenuhi permintaan orang tuanya. Selalu berusaha agar kedua orang tua merasakan bahwa anaknya juga ikut merasakan apa yang dirasakan oleh kedua orang tuanya. Apabila berjalan bersama tidak mendahuluinya. Apabila orang tua jauh selalu menanyakan keadaannya dengan berkirim surat. Sikap anak seperti ini merupakan sikap anak yang diridhai oleh Allah dan kedua orang tuanya. ${ }^{32}$

Berbuat baik (berbakti) kepada kedua orang tua itu wajib meskipun mereka keduanya (salah satunya) kafir atau fasik (durhaka kepada Allah swt.). Hanya saja, si anak tidak boleh mengikutinya jika mereka memaksa untuk bermaksiat kepada Allah swt. ${ }^{33}$ Hak orang tua adalah mendapatkan perlakuan baik dari anak-anaknya dan merupakan kewajiban anak untuk senantiasa berbuat baik kepada orang tuanya.

\section{Berbagai Pandangan Ulama Kota Banjarmasin Terhadap Penempatan Orang Tua Lanjut Usia Oleh Anaknya di Panti Jompo}

1. Pendapat 3 orang ulama yang menyatakan bahwa boleh atau tidaknya tindakan anak yang menempatkan orang tuanya di panti jompo itu tergantung dari niat awalnya serta kondisi kehidupan anak, seperti persepsi ulama MH, ABK, MM. Tanggapan mereka pada umumnya bersifat netral, tidak menyalahkan dan juga tidak membenarkan namun memungkinkan untuk memperbolehkan apabila memang kondisinya darurat.

Jika si anak kondisi kehidupannya memang tidak mampu untuk mengurus dan merawat orang tuanya di rumah dalam bentuk pelayanannya, seperti memberi nafkah, memberikan pelayanan kesehatan yang baik kepada orang tuanya karena lanjut usia kondisinya lemah sering sakit-sakitan, maka keputusan untuk menitipkannya di panti jompo adalah solusi yang terbaik. Daripada si anak harus memaksakan diri untuk merawat orang tuanya sendiri, sedangkan kondisi kehidupannya yang tidak memungkinkan (tidak berkecukupan), maka tempat seperti panti jompo untuk orang tuanya merupakan yang terbaik.

Seharusnya panti jompo pun ikut aktif meneliti latar belakang keluarga yang ingin menitipkan orang tuanya (diseleksi). Namun, setelah orang tua di tempatkan di sana, jangan sekali-kali anak seperti membuang barang dan harus menengok atau menghiburnya sekedar mendengar curhatannya secara rutin.

2. Pendapat 6 orang ulama yang menyatakan durhaka anak yang menempatkan orang tuanya di panti jompo karena kewajiban seorang anak untuk berbakti kepada orang tuanya. Mereka adalah MKA, MS, M, IMH, AK, BI.

\footnotetext{
${ }^{31}$ Hasan Ayyub, Etike Islam..., h. 321.

${ }^{32}$ Hasan Ayyub, Etika Islam..., h. 322.

${ }^{33}$ Hasan Ayyub, Etika Islam..., h. 327.
} 
Secara keras dan tegas mereka mengatakan durhaka anak yang mampu merawat orang tuanya, namun memilih menitipkannya di panti jompo, karena memang kewajiban anak untuk merawat orang tua yang sudah tidak mampu (lanjut usia) dengan sebaik-baiknya.

Kalau alasan kesibukan sehingga tidak bisa mengurus atau memelihara orang tuanya di rumahnya dan khawatir kalau tergolong durhaka. Sebenarnya kesibukan itu bisa diatur, kapan bekerja dan kapan mengurus orang tua, atau bisa juga isteri dan anak-anaknya yang mengurusnya. Kalau itu juga tidak bisa maka solusi terbaiknya adalah dengan mempekerjakan seseorang di rumah baik itu orang lain maupun dari pihak keluarga sendiri, yang tentunya dekat dengan orang tuanya yang bersedia membantu merawatkannya.

Bagi anak yang tidak mampu sekalipun hendaknya mengusahakan memelihara orang tua bersamanya. Apalagi orang tua yang memiliki banyak anak, bisa saja si A yang kehidupannya kurang mampu merawat orang tuanya dan saudaranya si B, si C dan lainnya membantu dalam hal ekonominya. Ingatlah, sesibuk apapun usaha orang tua waktu merawat anaknya yang masih kecil, tetaplah mereka menyempatkan waktu untuk melihat perkembangan dan pertumbuhan buah hatinya.

\section{Peran Ulama di Tengah-tengah Masyarakat sebagai Tokoh yang Memberikan Kesadaran Agama}

Peran dan tugasnya para ulama dalam permasalahan ini adalah memberikan ceramah baik itu berupa nasehat maupun anjuran untuk berbakti kepada orang tua, yang diharapkan dapat memberikan kesadaran kepada masyarakat bahwa berbakti kepada kepada orang tua merupakan kewajiban, apalagi di saat keduanya atau salah satunya sampai berusia lanjut dan dalam pemeliharaan anak.

Dijelaskan oleh para ulama di atas, balasan bagi anak durhaka dan keutamaan yang di dapat anak yang berbakti kepada orang tua:

Balasan bagi anak yang durhaka terhadap orang tuanya:

1. Haram masuk surga.

2. Dimurkai Allah swt.

3. Mendapat dosa besar.

4. Disegerakan azabnya di dunia.

5. Tidak diterima amal kebaikannya. Walaupun seseorang telah melakukan beribu-ribu kebajikan, tetapi tidak melakukan bakti kepada ibu dan ayah, maka kebajikannya hanya sia-sia belaka.

6. Jika orang tuanya mendoakan yang buruk terhadap anaknya yang durhaka, maka Allah akan segera mengabulkan doa jelek terhadap anaknya tersebut.

Ganjaran kebaikan bagi anak yang berbakti kepada kedua orang tuanya:

1. Pahala.

2. Dimudahkan-Nya rezeki.

3. Mendapatkan keridhaan Allah swt., karena orang tua meridhai.

4. Mendapat keberkahan hidup/kebaikan yang banyak dari Allah swt.

5. Do'a orang tua. 
6. Kesuksesan.

7. Kebahagiaan hidup dunia dan akhirat.

Allah swt. menjanjikan balasan keburukan bagi anak yang durhaka dan ada pula ganjaran kebaikan bagi anak yang berbakti kepada orang tuanya.

\section{Analisis}

Perspektif etika Islam terhadap pandangan ulama: ulama yang bersikap netral karena memaklumi terhadap situasi dan kondisi kehidupan yang tidak mampu dan untuk kebaikan orang tuanya sehingga si anak memutuskan panti jompo sebagai solusinya dan dengannya dapat dilihat adanya kecintaan karena menginginkan agar orang tuanya lebih terawat. Seperti pemikiran Ibnu Miskawaih, seseorang tidak bisa dikatakan adil, kalau dia belum melaksanakan apa yang terbaik bagi keluarganya. Kalau memang di panti jompo orang tuanya bisa terawat dan lebih baik, maka perbuatan anak tersebut bisa dikatakan sebagai bentuk perbuatan baik karena tidak ingin melihat orang tuanya hidup menderita kalau dipaksakan tinggal bersamanya yang kehidupannya pun serba sulit. Kemudian, pendapat ulama yang keras dengan tegas menyatakan bahwa tanggung jawab anak dan hak orang tua atas anaknya itu hanya bisa dipenuhi dengan tinggal bersama dalam keluarga, karena dengannya anak dapat mengabdikan diri untuk berbakti kepada orang tuanya. Anak dapat menunjukkan darma baktinya kepada orang tua hanya dengan cara berbuat baik kepada keduanya, sebagaimana ditetapkan oleh Islam, seperti pendapat Nashir al-Din Thusi dan Imam al-Ghazali sudah menjelaskan adab seorang anak terhadap orang tua.

\section{Penutup}

Dari hasil penelitian yang dilakukan terhadap 9 orang ulama kota Banjarmasin atas persepsi mereka terhadap tindakan anak yang menempatkan orang tuanya di panti jompo ada dua kategori: pertama, pendapat ulama yang netral, membolehkan saja apabila keadaannya darurat, dalam artian kehidupan anak tersebut sangat miskin dan untuk kebaikan orang tuanya sehingga dengan terpaksa dititipkan di panti jompo. Kedua, pendapat ulama yang keras, menolak dengan tegas dan tidak membenarkan hal tersebut serta menghukumi sebagai tindakan yang durhaka, apabila sebenarnya anak mampu karena ada solusi terbaik yaitu dengan mempekerjakan orang lain untuk merawatkan orang tuanya. Untuk memberikan kesadaran agama, bahwa berbakti kepada orang tua sangatlah diperlukan peran ulama dalam meningkatkan rasa tanggung jawab anak terhadap orang tuanya. Tugas para ulama adalah mengembalikan masyarakat dari yang berpikir individualistik-materialistik (budaya barat) ke pada jiwa yang lebih sosialistik dan bertanggungjawab. Jangan sampai seperti peribahasa "kacang yang lupa kulitnya." Tetapi, jadilah rumpunan pohon pisang, yang mana saat masih berbentuk tunas sampai tumbuh tinggi dan bahkan sudah berbuah, dia akan tetap didekat induknya.

Kedua pandangan ulama tersebut baik yang netral maupun yang keras sama-sama mempunyai dasar etika Islam yang kuat dan sejalan dengan pemikiran para filsuf Islam. 


\section{DAFTAR PUSTAKA}

Abu Ghuddah, Abdul Fattah, 35 Adab Islam, Jakarta: Pustaka Al-Kautsar, 1996.

Al-Ahdal, Abdullah Ahmad Qodiry. (1992).Tanggung Jawab dalam Islam, Cet. ke-3. Semarang: Dina Utama.

Al-Qur'an Digital.

Ayyub, Hasan, Etika Islam (Menuju Kehidupan Yang Hakiki), terj. Tarmana Ahmad Qasim, H. Sofyan, Endang Suhinda, Bandung: Trigenda Karya, 1994, cet.1.

Basyir, Ahmad Azhar. Refleksi Atas Persoalan Keislaman, Seputar Filsafat Hukum, Politik dan Ekonomi, Bandung: Mizan, 1994.

Adz-Dzahabi, Imam. (2005). Dosa-dosa Besar: Kunci Masuk Surga Bagi yang Menghindarinya, terj. Muammal Hamidy. Cet. II. Surabaya: PT. Bina Ilmu.

Al-Ghazali, Imam., (1997). Risalah-risalah Al-Ghazali, terj. Irwan Kurniawan, Cet. I. Bandung: Pustaka Hidayah.

- (2013).Bidayatul-Hidayah (Permulaan Jalan Hidayah), terj: Ahmad Fahmi bin Zamzam (Abu Ali Al-Banjari An-Nadwi Al-Maliki), Cet. I. Banjarbaru: Toko Buku "Darussalam Yasin".

Ilyas, Yunahar. (1999). Kuliah Akblaq, Yogyakarta: Lembaga Pengkajian dan Pengalaman Islam (LPPI).

Masyhur, Kahar. (1994). Membina Moral dan Akhlak, Jakarta: Rineka Cipta.

Miskawaih, Ibn. (1999). Menuju Kesempurnaan Akblak: Buku Daras Pertama Tentang Filsafat Etika, Terj. Helmi Hidayat. Cet ke-5. Bandung: Mizan.

Rahmadi. (2008). Guru dan Murid dalam Perspektif Al-Mawardi dan Al-Ghazali, Cet. I. Banjarmasin: Antasari Press.

Rahmaniyah, Istighfarotur. (2010). Pendidikan Etika, Konsep Jiwa dan Etika Perspektif Ibnu Miskawaih dalam Kontribusinya Di Bidang Pendidikan, Malang: UIN-Maliki Press.

Salam, Burhanuddin. (1997). Etika Sosial Asas Moral Dalam Kehidupan Manusia, Jakarta: Rineka Cipta.

Syarif M.M. (1996). History of Muslim Philosophy, terj. Bandung: Mizan.

Thalib, M. (1996). 20 Perilaku Durhaka Anak Terhadap Orang Tua, Bandung: Irsyad Baitus Salam/ IBS.

. 40 Tanggung Jawab Anak Terbadap Orang Tua, Bandung: Irsyad Baitus Salam/IBS, 1995.

. (2001). Seni \& Sikap Islami Mendidik Anak, Cet. I. Bandung: Irsyad Baitus Salam.

Zar, Sirajuddin. (2010). Filsafat Islam: Filosof \& Filsafatnya, Jakarta: Rajawali Pers. 